\title{
COMPARISON OF LUXURY BRAND PERCEPTION: OLD (UK) VS. MODERN (RUSSIA) CONSUMERS' PERCEPTION TOWARD THE BURBERRY BRAND
}

\author{
Irina Skorobogatykh, Olga Saginova, Zhanna Musatova \\ Plekhanov Russian University of Economics, Moscow
}

\begin{abstract}
With globalization and increased mobility consumers can easily access the same brand in different markets, interpreting the meaning and the social statuses they represent. That is why maintaining brand consistency across countries should be of great importance for companies' brand management and marketing strategies, especially in the luxury industry where profitability and long-term success rely on consumers' perceptions of luxury brands. This paper examines brand image consistency of luxury brands in the fashion industry, through an exploratory study of consumers' perception of the Burberry brand in the UK and Russia.
\end{abstract}

Keywords: brand perception, luxury brands, fashion industry, Burberry brand, brand image, brand associations, crosscultural influence

\section{INTRODUCTION}

The process of branding is generally defined as building, implementing, maintaining and enhancing strong brands, which evoke brand awareness and favorable brand image that mirror the brand's identity (Hoeffler \& Keller, 2003). Strong brands are able to leverage positive evaluations of the brands held by consumers to advantages in their purchasing behavior and responses to companies' marketing activities (Hoeffler \& Keller, 2003; Keller, 1993).

Although global brands have become prevalent in international markets, little attention has been paid to brand perception consistency across countries. Brand inconsistency endangers a brand's identity in terms of brand personality and brand image. Consequently, it harms brand equity and jeopardizes the company's performance in global markets. Furthermore, with increasing cross-border population mobility and the development of international media, markets are becoming more integrated than ever before (Douglas, Craig \& Nijssen, 2001). As a result, consumers can easily access the same brand in different markets, interpreting their meaning and the social statuses they represent. Thus, maintaining brand consistency across countries should be of great importance to companies' brand management and marketing strategies, especially to the luxury industry whose profitability and long-term success rely on consumers' perceptions of brands.

Reflecting the capability of consumers to recognize and recall a particular brand and relate it to a certain product in different circumstances (Aaker, 1991), brand awareness is vital for brands because it is the prerequisite of all other communication effects (McDonald \& Sharp, 1996). The central aspect of brand awareness is the deployment of information in memory that enables the development of brand associations which result in a particular brand image (Pitta \& Katsanis, 1995). Brand image is the combined effect of brand associations (Beil, 1992; Engel, Blackwell \& Miniard, 1993). Consumers form brand images through a synthesis of all signals emitted by the brand (Kaperfer, 1992).

The associative memory network model constitutes the basis to understand how brand associations form brand image (Biel, 1992; Hoeffler \& Keller, 2003; Keller, 1993). Keller (1993) divided brand associations into three types: (a) attributes that describe the features of a product or service, (b) benefits that indicate the personal value attached with a product or service, and (c) attitudes that define consumers' overall evaluation of a brand. These different types of brand associations make up brand images and include product-related or non-product-related attributes; functional, experiential, and symbolic benefits and overall brand attitude.

The image that consumers have in mind about the brand needs to be examined regularly as it reveals the brand's current situation in the market and provides a basis for future marketing planning. Brand associations are important for marketers to be aware of as they use the associations to "differentiate, position, and extend brands, to create positive feelings and attitudes towards brands, and to suggest attributes or benefits of purchasing or using a specific brand" (Low \& Lamb, 2000, p. 27).

As part of the global marketing strategy, the choices of standardizing or localizing brand image in global markets are affected by cross-culture differences (Roth, 1995). Culture difference across markets is an indicator 
that consumers in different markets have different needs; hence, great culture difference may require tailoring the brand image to these needs and customer perceptions.

Culture and socioeconomics significantly differ in developed and transition economies. Brands that are generally perceived in developed markets as standard or affordable tend to be perceived as more luxurious in emerging markets. There are also additional regional variations within product types. In May 2013, Euromonitor International Analyst Pulse survey showed that the perception by analysts, of brands such as Burberry, Rolex, Tag Heuer, Chanel, and Clinique, differ across regions, with differences amounting to 815\% (Holmes, 2013).

When buying luxury goods, consumers show different inclinations in their buying behaviors. Buyers in both developed and emerging markets appear to be cost-conscious with regard to luxury goods. However, this attitude translates to variations in typical buying behaviors.

Buyers in developed markets prefer affordable luxury products or luxury products that are highly discounted (i.e., during a sale or a limited time offer). These buyers are also more likely to seasonally purchase luxury products, as gifts. Buyers in emerging markets prefer to buy luxury products abroad or at duty-free areas, where these products often cost less than in their home countries. Cost-consciousness is also more likely to show itself via purchases of imitation luxury products in emerging markets. Here, the appearance of luxury sometimes matters more than an authentic luxury good or store experience. The heightened status associated with buying and wearing luxury brands, instead of standard brands, still matters for many consumers. In the global market for luxury goods, historically premium brands, such as Burberry, are competing with standard brands entering emerging markets (Holmes, 2013).

In this situation, luxury fashion brands-as symbols of status-should maintain brand image consistency across markets. The inconsistency of brand image in the home country and remainder of the markets can undermine the perceived value of luxury brands. Consistency is identified as a key element that contributes to a strong brand (Melewar \& Sambrook, 2004). The extent to which a brand image is perceived similarly across nations can be an indicator of brand globalization (Hsieh, 2001). Global brands are associated with higher prestige or status; perceived global level of brands could create consumer perceptions of brand superiority (Kapferer, 2005). Lack of maintaining image consistency for similar target markets may result in consumer confusion and reduced consumer loyalty (Melewar \& Sambrook, 2004), thus affect the long-term success of the business.

In addition, the development of a unique brand image across countries is especially important in certain product categories when brands target worldwide segments of consumers (Hassan and Katsanis, 1994). With the spread of international media, the ease of information flow, and the movement of population across national borders, the inconsistency of brand image in markets may influence consumers' overall evaluation of global luxury brands, which are expected to be international symbolic representations. The increasing level of integration of markets requires global fashion brands to deliver their brands consistently across countries in order to maintain customer bases in every market.

\section{RESEARCH}

Burberry, founded in 1856, became known for its outdoor wear and military style officer's raincoat, which is lined in Burberry's trademarked distinctive check-a well-known and recognizable fashion brand in many countries. The expansion of Burberry product ranges and foreign market distribution created considerable challenges by late 1990s (Cowe, 1998). These challenges included: (a) heavy reliance upon a small base of core products; (b) company-owned retail network based within non-strategic locations; (c) inconsistent wholesale distribution strategy with Burberry products being sold in a wide range of retail environments of varying quality; and (d) poorly controlled licensing strategy which resulted in inconsistencies in prices, design, and quality control across markets, etc. The new company strategy repositioned the Burberry brand as a distinctive luxury brand with a clear design, merchandising, marketing, and distribution strategy, which could appeal to new, younger, fashion-minded customers. A flagship store, that opened on New Bond Street in London, placed Burberry next to the other leading high fashion and luxury brands such as Gucci, Versace, Chanel, Prada, and YSL (Moore \& Birtwistle, 2004).

This research aimed to explore whether the Burberry brand is perceived consistently between British and Russian consumers. The choice of countries for comparison is explained by the following reasons:

- A comparison of the brand in its home market and foreign markets. Established in Britain, Burberry is expected to have higher awareness in its home country. Moreover, with direct operations and strong control of the company in home market, British consumers are directly exposed to the company's branding strategy. In contrast with the company's operation through a third party in Russia, Russian consumers may have vague understanding of the brand compared to British consumers.

- A comparison of the brand between Western and Eastern European/Asian cultures. Representing Western and Asian values, consumers from Britain and from Russia probably hold a different understanding of the brand.

As the literature review identified, brand image is the 
combined effect of brand associations and brand personality. Taking brand awareness as the prerequisite of the formation of brand image into consideration, the following hypotheses were derived:

H1: British and Russian consumers have different level of brand awareness toward Burberry.

H2: British and Russian consumers hold different brand associations toward Burberry.

H3: British and Russian consumers have a different understanding of brand personality embodied by Burberry.

H4: British and Russian consumers hold different brand images of Burberry.

The comparison of differences in consumer perception of Burberry requires not only identifications in nature but also accurate data support. A quantitative research method, which used a self-completion questionnaire, was adopted to serve the purpose. The self-completion questionnaire contained nine questions in four sections; each section explored one aspect of consumer perception of the Burberry brand.

The first section investigated consumers' awareness of Burberry, using a simple dichotomy response type question to test brand name awareness and multiplechoice questions to examine consumers' knowledge about Burberry's business scope.

The second section investigated brand associations in consumers' minds toward the Burberry brand. Fourteen features, grouped into three parts, examined the functional, emotional, and self-expressive associations accordingly. Respondents were asked to indicate the level of association for each feature using a five-point Likert scale.

The third section examined brand personality of the Burberry brand. Respondents were asked to indicate their level of agreement on twelve personality statements.
The fourth section concerned determinants of clothing purchase. Five different determinants were examined (e.g., quality, design, brand, price and self-expression). Participants were asked to identify the importance of each factor on a five-point Likert scale.

Since Burberry consumers are around the average age of thirty and the company sets a new target market at ages 18-24 (Nguyen, 2003). The questionnaires were distributed to young consumers in both Russian and Britain. Questionnaires in Russia were distributed randomly and an E-mail survey was carried out in Britain. Ninety questionnaires were distributed and collected in Britain and 160 in Russia; the average response rate was $68.2 \%$.

\section{RESEARCH RESULTS AND DISCUSSION \\ Brand Awareness}

Although British consumers demonstrate higher brand name awareness, the knowledge about Burberry's business held by consumers in the examined markets showed some similarity (see Table 1). For both British and Russian consumers, men's and women's wear were the most well-known business of Burberry, followed by fragrance and accessories. However, children's wear was the least known among British consumers whereas golf wear gained limited awareness among Russian consumers. This can be explained by the social circumstance in Russia that golf is conceived to be a leisure activity for noble and is popular only among the wealthy. According to the results, $30 \%$ of the British respondents indicated full awareness of Burberry's business scope. In contrast, $6.67 \%$ of the British respondents were only aware of a single sector that Burberry engaged in. The figures for Russian consumers were $20.40 \%$ versus $6.12 \%$. Overall, the awareness of Burberry's business scope in British consumers was slightly higher than that in Russian consumers, despite the relatively obvious difference in Golf Wear.

Table 1 Awareness of Burberry's Business Scope

\begin{tabular}{|l|l|l|l|l|l|l|}
\hline & $\begin{array}{l}\text { Men's } \\
\text { Wear }\end{array}$ & $\begin{array}{l}\text { Women's } \\
\text { Wear }\end{array}$ & Children's Wear & Golf Wear & Accessories & Fragrance \\
\hline British & $96.67 \%$ & $93.33 \%$ & $43.33 \%$ & $50 \%$ & $70 \%$ & $73.33 \%$ \\
\hline Russian & $89.80 \%$ & $87.76 \%$ & $38.78 \%$ & $71.43 \%$ & $71.43 \%$ & $71.43 \%$ \\
\hline
\end{tabular}

Chi-square test was conducted to determine whether difference in brand awareness of business scope between British and Russian consumers is significant. As identified by Pallant (2001), a significant value no larger than .05 identifies significant difference. The Pearson Chi-square value of the test is .796, which implies the difference of brand awareness of Burberry's business scope between British and Russian consumers is not significant. As discussed before, Burberry brand name awareness in British consumers exceeds that in Russian consumers; the difference of the level of brand name awareness between the two cultures is significant. Furthermore, the awareness of Burberry's business scope of British consumers is slightly higher than Russian consumers. Overall, British consumers are more aware of the Burberry brand. Thus, Hypothesis 1 was 
supported.

\section{Brand Associations}

The difference in brand associations between British and Russian consumers was measured by comparing the level of possibility that respondents from two countries associated identified features with Burberry. In total, 15 identified features were included. A reliability test was conducted first in order to check the scale set for measuring brand associations. With a Cronbach alpha coefficient of .934 which is greater than the recommended value of .7 (Pallant, 2001).

Among the 15 items, 14 were strongly correlated with the Alpha value of reliability. Only the item "Distinctive" showed the value of .302 of item-total correlation, which indicated that the item had weak contribution to the scale of brand association. Results indicated that removing the item "Distinctive" would increase the reliability of the scale to .939 . Thus, the following analysis excluded "Distinctive" from the scale.

After examining the reliability of the scale of brand association, a correlation analysis was conducted to examine the strength and direction between each item and the overall association of Burberry. The value of Pearson correlation (r) is presented in Table 2.

Table 1: Coefficient Estimates of Logistics Regression models related to CEO turnover

\begin{tabular}{|c|c|c|}
\hline $\mathrm{r}=.10$ to. 29 & or.-10 to. -29 & Small \\
\hline $\mathrm{r}=.30$ to. 49 & or.-30 to. -49 & Medium \\
\hline $\mathrm{r}=.50$ to1.0 & or .50 to- 1.0 & Large \\
\hline
\end{tabular}

Adapted from Pallant, J., (2001). SPSS survival manual: a step by step guide to data analysis using SPSS. Chicago: Open University Publishing.

All 14 items included in the analysis showed positive correlation with the overall brand association. Consistent with the reliability test, 14 items illustrated strong strength and significant correlation with the overall association, with the value of Pearson correlation, $r$ more than .5. Among the 14 strongly related items, "Glamorous", "Prestigious" and "High-status" had the strongest relationship with the overall brand association.

An independent-samples t-test was conducted to compare the difference of brand associations between British and Russian consumers, by comparing the mean score of each variable. Whether there is a significant difference between the two groups refers to the "Sig. (2 tailed)" value provided in the results. The "Sig. (2 tailed)" value that is equal or less than .05 indicates significant difference between the two groups while the value above .05 indicates no significant difference. With values of significance of all 14 items below .05 , the results of t-test indicated that there were significant differences between British and Russian consumers concerning the 14 brand associations.

After identifying the existence of the significant difference between the two groups, effect size was examined to assess the magnitude of the difference. Cohen's (1988) guidelines for interpreting Eta squared are: $.01=$ small effect, $.06=$ moderate effect, $.14=$ large effect.

Among those 14 items, the magnitude of the differences in the means of "Good design" (Eta squared $=0.10$ ) and "Successful" (Eta squared $=0.11$ ) were moderate, whereas the other 12 items showed large effect of difference between means. Details of effect size are shown in Table 3.

Table 3 Eta Squared Values of Brand Associations

\begin{tabular}{|l|l|l|}
\hline Associations & T Value & Eta squared \\
\hline High Quality & 4.056 & 0.176 \\
\hline Good Design & 2.931 & 0.1 \\
\hline Formal Dress & 5.952 & 0.315 \\
\hline Classic & 7.223 & 0.403 \\
\hline Stylish & 5.362 & 0.272 \\
\hline Luxurious & 8.647 & 0.493 \\
\hline Glamorous & 8.354 & 0.475 \\
\hline Tasteful & 6.786 & 0.374 \\
\hline Fascinating & 9.655 & 0.548 \\
\hline Exclusive & 5.428 & 0.277 \\
\hline Leading & 5.016 & 0.246 \\
\hline
\end{tabular}

Viewing Eta squared values as percentages can illustrate variance of each variable explained by the grouping variable, which in this case is nationality. As shown in table 3,54.8\% of variance in the association of "Fascinating" is explained by nationality. Along with "Fascinating", "Luxurious", "Prestigious", "Glamorous" and "High-status Symbol" are the associations whose variance are strongly related to nationality, with over $45 \%$ variance are explained by nationality.

Although Russian consumers also consider associating "Successful" with Burberry $(11=4.16$ on a five-point Likert scale), the three highest ranked associations were "High quality" (11 =4.33 on a fivepoint Likert scale), "Luxurious" (11 $=4.33$ on a fivepoint Likert scale) and "High-status symbol" (11 =4.37 on a five-point Likert scale). Unlike Russian consumers, British consumers were not likely to hold these 
associations toward Burberry with the indication of $11<$ 3 on a five-point Likert scale. Moreover, Russian consumers have higher evaluation on the brand as a result of very likely (11>4 on a five-point Likert scale) to associate the brand with characteristics that reflect the luxury positioning of Burberry. In contrast, the evaluation in British consumers is much lower and the brand is not likely to be perceived as a luxury brand ("Luxurious" $\mathrm{p},=2.73$ and "High-status symbol" 11 $=2.43$ on a five-point Likert scale), which is inconsistent with Burberry's brand positioning and global brand image.

Similarly, before conducting an independent-samples t-test to explore the different perceptions in terms of brand personality between British and Russian consumers, a reliability analysis and a Correlation test were conducted to examine the internal consistency of the scale and correlation between dimensions and brand personality as a whole.

With a Cronbach alpha coefficient of $.861>.7$ (Pallant, 2001), the brand personality scale shows good internal consistency. However, the Cronbach alpha coefficient can be improved by removing three items that with low values in corrected item-total correlation: "Feminine", "Masculine" and "Tough", which indicates that these three items do not as closely correlate to brand personality as other items. Thus, "Feminine", "Masculine" and "Tough" were excluded for further analyses.

Among the remaining 12 dimensions of brand personality, 11 dimensions indicated strong positive correlations $(\mathrm{r}>.5)$ and "Successful" showed medium ( $\mathrm{r}=.432$ ) strength of correlation with brand personality.

The independent-samples t-test resulted in consistent outcomes with the reliability and correlation analysis. Eleven items showed significant difference between British and Russian consumers in terms of brand personality embodied with Burberry, as their significant values were far below .05. There was no significant difference between British and Russian consumers concerning "Successful" to be a dimension Burberry's personality (significance value 0.315 ).

The effect size analyses that assesses the magnitude of the differences between British and Russian consumer groups are presented in Table 4.

Among those dimensions that showed significant differences between the two groups of consumers, the magnitude of the differences in the means of "Trendy", "Imaginative" and "Confident" were medium, comparing to the large differences of eta squared of the rest. There was no significant difference in the mean of "Successful" between British and Russian consumers, which indicated that consumers from the two markets both consider "Successful" to represent Burberry's personality. An Independent-samples t-test targeting the difference of the overall brand personality between British and Russian consumers was conducted after examining each dimension of the scale. The result suggests a significant difference (Sig. value .000) concerning brand personality between consumers in the two countries.

Table 4 Eta Squared Value of Dimensions of Brand Personality

\begin{tabular}{|l|l|l|}
\hline Personality & T value & Eta squared \\
\hline Original & 4.141 & 0.182 \\
\hline Sentimental & 6.195 & 0.333 \\
\hline Trendy & 3.082 & 0.11 \\
\hline Exciting & 4.302 & 0.194 \\
\hline Imaginative & 2.655 & 0.084 \\
\hline Reliable & 4.928 & 0.24 \\
\hline Uniue & 4.53 & 0.21 \\
\hline Intelligent & 5.52 & 0.284 \\
\hline Successful & 1.011 & 0.013 \\
\hline Confident & 2.899 & 0.098 \\
\hline Charming & 5.45 & 0.278 \\
\hline Elegant & 7.646 & 0.432 \\
\hline
\end{tabular}

Despite three dimensions excluded from the analyses which were testified to be less consistent with the scale of brand personality, there were significant differences between British and Russian consumers concerning their perception of brand personality embodied in Burberry, excluding a single item of "Successful" which contains medium strength of correlation to brand personality compared with others' strong correlation. Thus, Hypothesis 3 was supported.

The results of independent-samples t-tests supports the hypotheses that British and Russian consumers held different associations and perceive different brand personality toward Burberry. The results indicated significant differences between British and Russian respondents in the overall brand associations and brand personality, which are the sum effect of their variables. However, the magnitude of the differences in brand associations (eta squared $=0.57$ ) is larger than $\mathrm{m}$ brand personality (eta squared $=0.42$ ), which represent $57 \%$ of variance $m$ brand associations whereas $42 \%$ of variance in brand personality is explained by nationality, though they both revealed large effect of differences between the two groups of consumers.

\section{Brand Image}

As discussed before, brand awareness is the prerequisite of the formation of brand image. Thus, the significant differences of brand awareness, brand association, and brand personality between British and Russian consumers imply that British and Russian consumers hold different brand image toward Burberry. Hypothesis 4 was thus supported. 
An independent-samples t-test was conducted to assess whether British and Russian consumers have different criteria for the decision-making of clothing purchase. Five aspects were examined, identified as quality, design, brand, price level and self-expression. The results indicated that there were no significant differences between these two groups of respondents in terms of the importance of quality and design to the choice of clothes. Both British and Russian consumers think quality and design are important criteria for clothing purchase (Il $>4$ on a five-point Likert scale). In addition, Russian consumers' consideration level of quality ( $\mathrm{Il}=4.59$ ) and design ( $\mathrm{Il}=4.67$ ) factors are higher than British consumers, as a result of comparing the means to $\mathrm{Il}=4.37$ and 4.40 on a five-point Likert scale. Nevertheless, the way British consumers and Russian consumers consider the importance of brand, price and self-expression in clothing purchase has significant differences as identified by the results. Russian consumers consider these three factors more important than British consumers. The fact that Russian consumers consider brand to be a very important factor (Il $=4.22$ on a five-point Likert scale) that influences their purchase behavior implies that occupying a unique stand point in Russian consumers mind firmly may benefit and facilitate the decision of purchasing the particular brand in the product category. Brand building and maintaining is vital for luxury fashion companies to achieve long-term profitability in the market. The requirement for self-expression in Russian consumers is higher than British consumers, with the mean of $\mathrm{Il}=$ 4.08 compared with $\mathrm{Il}=3.33$ on a five-point Likert scale. For Russian consumers, clothing is considered to be a code that matches their self identities. Thus, conveying brand images through brand personality and marketing communication in a way that matches target consumers' self perception plays an essential role in increasing brand performance in Russia.

The statistic analyses identified significant differences toward Burberry between British and Russian consumers concerning brand awareness, brand associations and brand personality. Consumers from the two countries hold inconsistent brand image of Burberry. The overall impression of Burberry does not positively increase with brand awareness in this case. According to the investigation, although British consumers have higher awareness of the Burberry brand they do not perceive Burberry to be a top luxurious fashion brand, which is not consistent with the company's branding plan. Because it is associated with high quality, distinctive, and successful, Burberry is more likely to be considered by British consumers as a brand with rich heritage that provides good products. The effect of inspiration and excitement that a luxury brand presses on consumers is totally absent in the case of Burberry in British consumers' minds. Nevertheless, far from the home country of the brand, Russian consumers perceive Burberry to be a luxury brand that represents prestige and high status, which is consistent with Burberry's positioning.

The phenomenon of an unfavorable brand image of Burberry held by British consumers is the result of specific situations within the country. After becoming a top luxury fashion brand which is considered to be "one of the most envied brand reinventions of recent years" (Bothwell, 2005), Burberry became a victim of its own success. For example, Burberry has been adopted by football hooligan culture. In 2003, several images of hooliganism showed troublemakers wearing Burberry jackets and caps (Roger, 2003). Moreover, the trademarked Burberry check was adopted by a British working-class group called "chavs" that once plastered the check across its Website and took to decking themselves out from head-to-toe in a similar-looking fabric. Additionally, a flood of counterfeit Burberry check appeared at market stalls across Britain, damaging Burberry's high-end brand image because it was associated with working-class groups. This significantly lowered the evaluation of the brand in consumers' minds.

Democratization risks brand image dilution while diversification risks pushing the brand down market and reducing its aspiration. Brand extension could bring short-term economic interest but risks jeopardizing the health and future of a brand. Therefore, return to luxury is now the task that many luxury brands face. After reaching out to the masses, marketers are now trying to recapture glamour and exclusivity. Restoring exclusivity in Britain is the means to narrow the gap of brand image in Burberry's home country and foreign markets and moving toward brand image consistency is a critical element for building strong global luxury brands.

\section{SUMMARY AND CONCLUSIONS}

Although British consumers had higher brand name awareness, the knowledge about Burberry's business held by consumers in both markets showed similarity. Research showed significant difference between British and Russian consumers in terms of brand personality embodied in Burberry. The way British consumers and Russian consumers consider the importance of brand, price, and self-expression in clothing purchases has significant differences. Russian consumers consider these three factors more. The requirement for selfexpression in Russian consumers is higher than British consumers. For Russian consumers, clothing is considered to be a code that matches their self-identities. Thus, conveying brand images through brand personality and marketing communication in a way that matches target consumers' self-perceptions plays an essential role in increasing brand performance in Russia.

The initial study about the Burberry brand for British and Russian consumers, which represents differences between Western and East European/Asian culture as well as home and foreign markets, indicated significant 
differences between British and Russian consumers' perceptions of Burberry. These differences include brand awareness, brand association, brand personality and brand image. While Russian consumers perceive the brand as a luxury fashion brand, consistent with the company's brand positioning, British consumers in the home market refuse to recognize Burberry's luxuriousness. Though consumers overseas currently consider Burberry to be a top luxury brand, the weak strength of the brand in its home market cannot provide an adequate driver for global operation. The brand image in a home country is suppose to be the guide and example for the international brand building plan. Weak or negative brand image in consumers' minds in the home country may seriously influence the evaluation of the brand once it has been realized by consumers in the foreign markets. The inconsistency of brand image confuses consumers and destroys self-image congruence, which will eventually endanger the brand in the global markets.

Recapturing exclusivity and returning to luxury is the challenge facing many luxury brands, including Burberry. Limiting accessibility and retracing exclusivity of the brand is the treatment for rebuilding Burberry as a top luxury brand in British consumers' minds, to narrow the gap of brand image between its home and foreign markets, and the path to achieve brand image consistency globally.

\section{REFERENCES}

Aaker, J. (1997). Dimensions of Brand Personality. Journal of Marketing Research, 34, 347-356.

Birtwistle, 0., Clarke, 1., \& Freathy, P. (1999). Store Image in the UK Fashion Sector: Consumer versus Retailer Perceptions. The International Review of Retail, Distribution and Consumer Research, 9 (1), 1-16.

Bothwell, C. (2005). Burberry versus The Chavs. The Monday Programme on BBC Two, 28 October 2005. http://news.bbc.co.uklllhi/business/4381140.stm

Cohen, J. (1988). Statistic power analysis for the behavioral sciences. Hillsdale, NJ: Erlbaum

Cowe, R. (1998). Burberry fails to weather Asian storm. The Guardian. 25 June.

Douglas, S. P., Craig, C. S., \& Nijssen, E. J. (2001). Executive insights: Integrating branding strategy across markets: Building internatinal brand architecture. Journal of International Marketing, 9(2), 97-114.

Engel, James F., Roger D. Blackwell \& Paul W. Miniard. (1993). Consumer Behaviour (7th ed.) Fort Worth,TX: The Dryden Press

Hassan S., \& Craft S. (2005). Linking global market segmentation decisions with strategic positioning options. Journal of Consumer Marketing, 22 (2), 81-89.Hoeffier, S., Keller, K. (2003). The Marketing Advantage of Strong Brands. Brand Management, 10(6), 421-445.

Holmes, L. (2013). Analyst Pulse: Economy, Standard, Premium or Luxury? Brand Perceptions Around the World. Retrieved http://blog.euromonitor.com/2013/08/ analyst-pulse-economy-standard-premium-or-luxurybrand-perceptions-around-the-world.html
Hsieh M. (2002). Identifying brand image dimensionality and measuring the degree of brand globalization: A crossnational study. Journal of International Marketing, 10(2), 46-67.

Kapferer, J.N. (2012) The New Strategic Brand Management: Advanced Insights and Strategic Thinking (5th ed). UK: Kogan Page.

Kapferer, J.N. (2005). The post-global brand. Journal of Brand Management 12 (5), 319-324.

Keller, K. L. (1993). Conceptualizing, measuring, and managing customer-based brand equity. Journal of Marketing, 57(1), 1-22.

Low G. S., \& Lamb, C.W. Jr, (2000). The measurement and dimensionality of brand associations. Journal of Product \& Brand Management, 9(6), $350-370$.

Macdonald, E.K., \& Sharp B.M. (2000). Brand Awareness Effects on Consumer Decision Making for a Common, Repeat Purchase Product: A Replication Understanding brand equity for successful brand extension. Journal of Business Research, 48(1) 5-15.

Melewar, T. C., \& Sambrook, L. (2004). The importance of brand power: a review of the European car market European Business Journal, 16(4), 167-177.

Moore, C.M., \& Birtwistle, G. (2004). The Burberry business model: creating an international luxury fashion brand. International Journal of Retail \& Distribution Management, 32(8), 412-422.

Nguyen V. (n.d.) Analysis of the luxury goods and apparel and footware industries. Retrieved january05, 2014, http://www.slideshare.net/omermirza/nguyen-28311887

Pitta D.A., \& Katsanis L. P. (1995). Understanding brand equity for successful brand extension. Journal of Consumer Marketing, 12(4), 51-64.

Pallant, J., (2001). SPSS survival manual: a step by step guide to data analysis using SPSS. Chicago, IL: Open University Publishing.

Roth Martin S. (1995), Socioeconomics on the Performance of Global Brand Image Strategies Journal of Marketing Research, 32(2), 163-175

\section{ABOUT THE AUTHORS}

Corresponding author: Irina Skorobogatykh, email: iskorobogatykh@gmail.com

Dr. Irina Skorobogatykh holds a PH.D and a Doctor of Sciences Degrees in Marketing, authored several books and articles on luxury brand management and evolution of marketing thought in Russia. Currently is Professor and Head of Marketing Department at Plekhanov Russian University of Economics in Moscow, Russia. 